\title{
ДОСВІД НАВЧАЛЬНО-МЕТОДИЧНОЇ РОБОТИ КАФЕДРИ ОТОРИНОЛАРИНГОЛОГІї
}

\author{
О. І. Яшан, Г. С. Протасевич, П. В. Ковалик, Ю. М. Андрейчин
}

ДВНЗ “Тернопільський державний медичний університет імені І. Я. Горбачевського МОЗ Украӥни”

\section{EXPERIENCE OF EDUCATIONAL-METHODICAL ACTIVITY OF THE DEPARTAMENT OF OTORHINOLARINGOLOGY}

\author{
O. I. Yashan, H. S. Protasevych, P. V. Kovalyk, Yu. M. Andreychyn \\ SHEI "Ternopil State Medical University by I. Ya. Horbachevsky of MPH of Ukraine"
}

\begin{abstract}
У представленій статті висвітлено аналіз навчально-методичних робіт, опублікованих викладачами кафедри оториноларингології Тернопільського державного медичного університету ім. І. Я. Горбачевського за період їі існування (3 1958 р. донині).
\end{abstract}

The article is devoted to the analysis of educational methodical works published by teachers of otolaryngologic department of the Ternopil State Medical University by I. Ya. Horbachevsky since 1958 till now.

Вступ. Головна мета навчально-методичної роботи медичного університету полягає в підготовці спеціалістів, здатних в умовах практичної охорони здоров'я клінічно мислити, оперативно приймати рішення як у типових, так і в нестандартних ситуаціях [1]. Саме над цим працювали в минулому і працюють нині викладачі кафедри оториноларингології, офтальмології та нейрохірургії Тернопільського державного медичного університету ім. І. Я. Горбачевського.

За період існування кафедри (з 1958 р. донині) iii працівниками опубліковано ряд навчально-методичних робіт стосовно вдосконалення навчально-методичного процесу. Наша робота присвячена аналізу цих публікацій.

Основна частина. Перша навчально-методична розробка відноситься до 1966 р. і являє собою раціоналізаторську пропозицію, присвячену оптимізації робочого місця при обстеженні студентами оториноларингологічного хворого. Цим питанням займався асистент $€$. I. Турович. Зокрема, ним запропоновано малогабаритний стіл для практичних занять 3 оториноларингології. Він $є$ доволі простим за конструкцією, зручним в експлуатації і дешевим у виготовленні. Суть пропозиції полягає в тому, що звичайний дерев'яний стіл площею в 1 квадратний метр розділено по діагоналі двома перпендикулярно розташованими листами фанерної перегородки висотою 55 см на 4 робочих місця. В верхньо-зовнішньому іiі куті встановлена електрична лампочка, в нижньо- зовнішньому - вимикач [2]. В подальшому раціоналізаторську пропозицію розробив доцент Р. Т. Лавецький. В 1979 р. він запропонував латероскоп, який дозволяє спостерігати процес операції особам, що знаходяться збоку від місця виконання операції. В латероскопі операційне поле проглядається згори i збоку від очей оперуючого [3].

Значна увага приділялась програмованому і тестовому контролю знань студентів на практичних заняттях. 31973 р. доцент Р. Т. Лавецький почав розробляти програмований контроль знань студентів 3 оториноларингології. Він опублікував дані порівняння програмованого та традиційного методів контролю якості засвоєння матерілу на практичних заняттях. При цьому перевага була надана програмованому контролю [4].

В 1974 році професор I. А. Яшан, доцент Р. Т. Лавецький, асистент А. Ф. Масик, асистент Г. С. Протасевич проаналізували деякі показники використання тестового контролю знань студентів на практичних заняттях з оториноларингології [5].

В подальшому проблемою тестового контролю знань студентів займався доцент Г. С. Протасевич. В 1996 р. він разом з завідувачами кафедр і курсів оториноларингології медичних вищих навчальних закладів України написали навчальний посібник “Тестові завдання по контролю знань студентів з оториноларингологіі”. В посібнику наведені тестові завдання для контролю знань студентів за трьома критеріями:

() О. І. Яшан, Г. С. Протасевич, П. В. Ковалик, Ю. М. Андрейчин 
1) відшукати повну та правильну відповідь на запитання; 2) відшукати всі правильні відповіді на запитання; 3) знайти помилку у відповідях на запитання. Кожен критерій включає по 20 запитань. В кінці посібника наведені еталони правильних відповідей на запитання тестового контролю [6].

Значна увага приділялась підготовці студентів на практичних заняттях з оториноларингології. Так, професор I. А. Яшан, доцент Г. С. Протасевич, доцент O. I. Яшан в 1998 р. запропонували методику інтенсифікації навчального процесу на практичних заняттях, яка застосовується досі на кафедрі оториноларингології, офтальмології та нейрохірургії Тернопільського державного медичного університету імені I. Я. Горбачевського [7].

В 1999 р. доцент Г. С. Протасевич, професор I. А. Яшан, доцент О. I. Яшан в своїй публікації висвітлили різні форми навчання, які застосовуються на практичних заняттях і сприяють студентам краще оволодіти практичними навичками при вивченні оториноларингології [8]. В 2000 р. доцент Г. С. Протасевич, професор I. А. Яшан, доцент О. І. Яшан, доцент П. В. Ковалик в своїй публікації описують деякі питання підготовки студентів до практичної діяльності на кафедрі оториноларингології. Автори навели елементи творчої діяльності студентів під час лекцій, практичних занять, роботи в студентському науковому гуртку, при написанні історії хвороби оториноларингологічного хворого. Підкреслено, що наведені елементи підготовки студентів до практичної діяльності дозволяють підвищити практичну підготовку майбутніх фахівців з оториноларингології [9]. Доцент Г. С. Протасевич разом з завідувачами кафедр і курсів оториноларингології медичних вищих навчальних закладів України в 2002 р. видали “Посібник до практичних занять з оториноларингологіi”, в якому навели методичні розробки до практичних занять і методичні розробки для самостійного вивчення студентами оториноларингології. Розроблено ситуаційні задачі до кожного практичного заняття, а також контрольні питання для визначення початкового рівня знань студентів. Тематичні плани лекцій і практичних занять подано з урахуванням профілізації факультетів. Посібник містить план обстеження оториноларингологічного хворого, схему історії хвороби, перелік практичних навичок, якими повинен оволодіти студент, та питання до диференціального заліку і іспиту [9, 10].

Важливим фактором в оволодінні практичними навичками $є$ написання студентом історії хвороби на отоларингологічного хворого. Доцент Г. С. Протасевич, доцент О. І. Яшан в 1998 р. описали методику написання студентами навчальної історії хвороби 3 оториноларингології. Підкреслено, що “студентська" історія хвороби є важливим елементом творчої діяльності студента при вивченні оториноларингології і що творча діяльність студента проявляється на всіх станах складання цього документа [11].

В 2004 р. доцент Г. С. Протасевич, професор П. В. Ковалик, професор О.І. Яшан, доцент Ю. М. Андрейчин, професор I. А. Яшан виклали вимоги до складання “студентської історії хвороби” на кафедрі оториноларингології, офтальмології танейрохірургії Тернопільського державного медичного університету імені I. Я. Горбачевського, а також вказали типові помилки, які допускають студенти при іï написанні [12].

Певне значення викладачі кафедри надають самостійній позааудиторній роботі студентів. Професор I. А. Яшан, доцент Р. Т. Лавецький, асистент А. Ф. Масик, асистент Г. С. Протасевич в 1979 р. видали методичні рекомендації з позаудиторної підготовки студентів до практичних занять 3 оториноларингології, в яких висвітлені рекомендації для підготовки до кожної теми практичних занять, розроблені контрольні запитання для підготовки до практичних занять, практичні навички, якими повинен оволодіти студент на кожному занятті, вказана основна і додаткова література. Рекомендації містять питання до іспиту, схеми обстеження хворого, план-завдання для позааудиторної підготовки студентів з оториноларингології [13].

В 2001 році доцент Г. С. Протасевич, професор П. В. Ковалик, доцент Ю. М. Андрейчин описали елементи творчої діяльності в процесі самостійної позааудиторної роботи студентів медичного факультету при вивченні оториноларингології. При цьому авторами наведені різні елементи творчої діяльності, які використовуються в процесі самостійної роботи студентів при підготовці до практичних занять [14].

Викладачі кафедри постійно впроваджують результати наукових досліджень у навчальний процес. В 2001 році доцент Г. С. Протасевич, професор П. В. Ковалик, доцент Ю. М. Андрейчин опублікували роботу, в якій описали впровадження наукових розробок у навчальний процес на кафедрі оториноларингології Тернопільської державної медичної академії імені І. Я. Горбачевського. Вказані теми, при викладанні яких використовуються результати наукових досліджень кафедри [15].

Велике значення викладачі кафедри надають інтеграції з іншими дисциплінами у викладанні оторинола- 
рингології. Доцент Г. С. Протасевич, професор I. А. Яшан, доцент О. І. Яшан в 1999 році написали роботу, в якій висвітлили питання інтеграції з іншими дисциплінами при викладанні оториноларингології. При цьому підкреслено, що викладання оториноларингології інтегрується з матеріалом, що викладається на кафедрах анатомії людини, гістології, топографічної анатомії, нормальної фізіології, патологічної фізіології, патологічної анатомії, нервових хвороб, терапії, хірургії, онкології, інфекційних хвороб, акушерства та гінекології, курсах офтальмології, реаніматології та анестезіології, урології, травматології, нейрохірургії, стоматології [16].

Професор І. А. Яшан, професор Д. І. Заболотний, доцент О. І. Яшан, доцент П. В. Ковалик, доцент Г. С. Протасевич в 1999 році видали підручник для медичних сестер “Медсестринство в оториноларингології', в якому подали основний матеріал з анатомії, фізіології, методик дослідження вуха, горла та носа, а також відомості про найчастіші захворювання ЛОР-органів і способи їх лікування. Особлива увага звернена на функції медичної сестри при обслуговуванні оториноларингологічних хворих в поліклініці, стаціонарі, під час операції та маніпуляційній [17].

Значна увага приділяється навчально-методичній роботі з інтернами. Так, в 1977 році професор I. А. Яшан, доцент Р. Т. Лавецький видали методичні рекомендації до семінарських занять для інтернів [18]. В 1998 році доцент Г. С. Протасевич, професор I. А. Яшан, доцент О. І. Яшан опублікували роботу, в якій поділились досвідом підготовки лікарів через інтернатуру на курсі оториноларингології. Підкреслено, що проходження інтернатури на кафедрі, яка розташованана на базі ЛОР-відділення обласної клінічної лікарні, має свої переваги, зокрема більшу узгодженість навчання на практичній базі і на кафедрі [19].

В 2003 році доцент Г. С. Протасевич, професор I. А. Яшан, професор П. В. Ковалик, професор О. І. Яшан, доцент Ю. М. Андрейчин більш детально описали підготовку фахівців- оториноларингологів в інтернатурі. При цьому автори навели мету інтернатури та переваги проходження очного циклу на базі обласної клінічної лікарні, де знаходиться кафедра

\section{Література}

1. Досвід навчально-методичної роботи кафедри патологічної фізіології / Ю. Е. Роговий, В. Д. Мислицький, Л. О. Філіпова [та ін.] // Мед. освіта.-2001.-№3.-С. 38-40.

2. Турович Е. И. Малогабаритный стол для практических занятий по оториноларингологии / Е. И. Турович // Тернопольский медицинский институт : научная конференция. оториноларингології. Підкреслено, що при кінцевому оцінюванні знань лікарів-інтернів поряд із вирішенням тестових завдань та комп'ютерним контролем віддається перевага традиційному способу - живому спілкуванні інтерна з екзаменатором [20].

У 2006 році проф. О. І. Яшан відвідав Віденський медичний університет, що стало підгрунтям низки публікацій про цей ВН3 і методик навчання у ньому [2123]. У 2008 проф. О. І. Яшан відвідав декілька навчальних закладів США, що знайшло відображення в іншій роботі [24]. В результаті стажування багатьох викладачів нашого університету в закордонних навчальних закладах у Тернопільському державному медичному університеті імені І. Я. Горбачевського було запроваджено нові методики навчання, зокрема: методику “єдиного дня", лінії практичних навичок, семестровий тестовий контроль знань студентів, нову форму організації самостійної роботи, програму дистанційного контролю знань, об'єктивний структурований клінічний іспит (ОСКI). Такі нововведення у навчальний процес ТДМУ дозволили підвищити якість підготовки студентів на кафедрі при опануванні такої складної дисципліни, як оториноларингологія.

Висновки: 1. У представленій публікації висвітлено основні питання організації навчально-методичної роботи на кафедрі оториноларингології за час іiї існування (1958-2010 роки), включаючи раціоналізаторські пропозиції, тестовий контроль, формування у студентів професійних знань та вмінь.

2. Значна увага приділена навчально-методичній роботі з інтернами, включаючи вирішення тестових завдань, комп'ютерний контроль, живе спілкування інтерна з екзаменатором при кінцевому оцінюванні знань лікарів-інтернів.

3. Запровадження новітніх освітніх технологій (методики “єдиного дня”, ліній практичних навичок, семестрового тестового контролю знань студентів, нової форми організації самостійної роботи, програми дистанційного контролю знань, об'єктивного структурованого клінічного іспиту) у навчальний процес на кафедрі дозволили підвищити якість підготовки студентів при опануванні такої складної дисципліни, як оториноларингологія.

8-я : материалы. -Тернополь : Б. и., 1966. - С. 330-332.

3. Лавецкий Р. Т. Латероскоп для ЛОР операционной / Р. Т. Лавецкий // Журн. ушных, носовых и горловых болезней. - 1979. - № 2. - С. 83.

4. Лавецький Р. Т. Порівняльна оцінка програмованого та традиційного методів контролю і навчання на практич- 
них заняттях по оториноларингології / Р. Т. Лавецький // Тернопільський медичний інститут : науково-методична конференція з питань оптимізації учбового процесу. 3-тя. -Тернопіль: Б. в., 1973. - С. 15-16.

5. Анализ некоторых показателей использования тестового контроля знания студентов по оториноларингологии / [Яшан И. А., Лавецкий Р. Т., Масик А. Ф., Протасевич Г. С.] // Научно-методическая конференция по оптимизации учебного процесса. 4-я. -Тернополь : Б. и., 1974. C. 37-38.

6. Тестові завдання по контролю знань студентів з оториноларингології : навчальний посібник / [Ю. В. Мітін, В. М. Васильєв, В. С. Чорний та ін.]. -К. : Б. в., 1996. - 176 с.

7. Яшан I. А. Методика інтенсифікації практичних занять з оториноларингології / Яшан І. А., Протасевич Г. С., Яшан О. І. //Актуальні питання оптимізації навчально-виховного процесу з оториноларингології//Актуальні питання навчально-виховного процесу у медичному вузі. - Тернопіль : Укрмедкнига, 1998. - Р. 1. - С. 114-116.

8. Протасевич Г. С. Деякі питання оволодіння практичними навичками з оториноларингології / Г. С. Протасевич, I. А. Яшан, О. I. Яшан // Сучасні проблеми підготовки фахівців у вищих медичних та фармацевтичних навчальних закладах I-IV рівнів акредитації MO3 України. - К. Тернопіль : Б. в., 1999. - С. 384-385.

9. Деякі питання підготовки студентів до практичної діяльності на курсі оториноларингології / [Протасевич Г. С., Яшан I. А., Яшан О. І., Ковалик П. В.] // Нові технології навчання в медичному вищому навчальному закладі. Тернопіль : Укрмедкнига, 2000.- С. 142-148.

10. Посібник до практичних занять з оториноларингології / [Ю. В. Мітін, В. М. Васильєв, Д. І. Заболотний та ін.]. -К. : Здоров'я, 2002. - 168 с.

11. Протасевич Г. С. “Студентська” історія хвороби важливий елемент творчої діяльності студента під час вивчення оториноларингології / Г. С. Протасевич, О. І. Яшан // Актуальні питання оптимізації навчально-виховного процесу у медичному вузі. -Тернопіль : Укрмедкнига, 1998. P. 1. - C. 78-82.

12. Оториноларингологічна “студентська історія хвороби” / Г. С. Протасевич, П. В. Ковалик, О. І. Яшан [та ін.] // Мед. освіта. - 2004. - № 2.-С. 37-39.

13. Методические рекомендации по всеаудиторной подготовке студентов к практическим занятиям по оториноларингологии / [Яшан И. А., Лавецкий Р. Т., Масик А. Ф., Протасевич Г. С.]. - Тернополь : Б. и., 1979. - 58 с.
14. Протасевич Г. С. Елементи творчої діяльності в процесі самостійної позаудиторної роботи студентів медичного факультету при вивченні оториноларингології / Протасевич Г. С., Ковалик П. В., Андрейчин Ю. М. // Сучасні аспекти організації самостійної позаудиторної роботи студентів, лікарів-інтернів, курсантів. -Тернопіль : Укрмедкнига, 2001.-С. 113-115.

15. Протасевич Г. С. Впровадження наукових розробок у навчальний процес на кафедрі оториноларингології / Протасевич Г. С., Ковалик П. В., Андрейчин Ю. М. // Мед. освіта. - 2001.- № 3. - С. 15-18.

16. Протасевич Г. С. Питання інтеграції у викладанні оториноларингології / Протасевич Г. С., Яшан I. А., Яшан О. I. // Проблеми інтеграції в медичному вищому навчальному закладі. - Тернопіль : Укрмедкнига, 1999. -С. 129-134.

17. Медсестринство в оториноларингології : підручник/ I. А. Яшан, Д. І. Заболотний, О. І. Яшан [та ін.]; за ред. I. А. Яшана. - Тернопіль : Укрмедкнига, 1999.-236 с.

18. Яшан И. А. Методические рекомендации к семинарским занятиям для интернов / И. А. Яшан, Р. Т. Лавецкий. Тернополь : Б. и., 1977. -39 с.

19. Протасевич Г. С. Досвід підготовки лікарів через інтернатуру з оториноларингології/ Протасевич Г. С., Яшан I. А., Яшан О. І. // Актуальні питання оптимізації навчально-виховного процесу у медичному вузі. - Тернопіль : Укрмедкнига, 1998.-P. 1.-С. 82-84.

20. Підготовка фахівців - оториноларингологів в інтернатурі / Г. С. Протасевич, І. А. Яшан, П. В. Ковалик [та ін.]// Мед. освіта. - 2003. - № 1. - С. 54-56.

21. Організаційна структура Віденського медичного університету / К. О. Пашко, О. В. Олійник, О. І. Яшан [та ін.]// Мед. освіта. -2006. - № 2. - С. 42-45.

22. Господарський І. Я. Університетська клініка Віденського медичного університету. Можливості запровадження досвіду в Україні / І. Я. Господарський, О. І. Яшан // Мед. освіта. - 2006. - № 2. - С. 57-60.

23. Особливості викладання оториноларингологіїу Віденському медичному університеті / О. І. Яшан, К. О. Пашко, С. І.Шкробот [та ін.]//Мед. освіта. -2006.-№2.-С. 95-102.

24. Яшан О. І. Етапи вищої медичної освіти у США / Яшан О. І., Ястремська С. О., Коноваленко С. О. // В кн. : Матеріали Всеукраїнської навчально-наукової конференції "Проблеми інтеграції української медичної освіти в світовий освітній простір”, 21-22 травня 2009 року, м. Тернопіль. -Тернопіль: Укрмедкнига, 2009.-С. 298-301. 